\title{
Factors associated with seizure and cognitive outcomes after epilepsy surgery for low-grade epilepsy-associated neuroepithelial tumors in children
}

\author{
Ara Ko, $\mathrm{MD}^{1}$, Joon Soo Lee, MD, PhD ${ }^{2}$ \\ ${ }^{1}$ Division of Pediatric Neurology, Department of Pediatrics, Pusan National University Children's Hospital, Pusan National University College of Medicine, Yangsan, \\ Korea; '²Division of Pediatric Neurology, Department of Pediatrics, Severance Children's Hospital, Yonsei University College of Medicine, Seoul, Korea
}

\begin{abstract}
Low-grade epilepsy-associated neuroepithelial tumors (LEATs) are responsible for drug-resistant chronic focal epilepsy, and are the second-most common reason for epilepsy surgery in children. LEATs are extremely responsive to surgical treatment, and therefore epilepsy surgery should be considered as a treatment option for LEATs. However, the optimal time for surgery remains controversial, and surgeries are often delayed. In this review, we reviewed published article on the factors associated with seizure and cognitive outcomes after epilepsy surgery for LEATs in children to help clinicians in their decision whether to pursue epilepsy surgery for LEATs. The achievement of gross total resection may be the most important prognostic factor for seizure freedom. A shorter duration of epilepsy, a younger age at surgery, and extended resection of temporal lobe tumors have also been suggested as favorable prognostic factors in terms of seizure control. Poor cognitive function in children with LEATs is associated with a longer duration of epilepsy and a younger age at seizure onset.
\end{abstract}

Keywords: Low-grade epilepsy-associated tumors, Epilepsy surgery, Prognosis, Cognition

\section{Introduction}

Low-grade epilepsy-associated neuroepithelial tumors (LEATs) are responsible for drug-resistant chronic focal epilepsy that presents with seizure onset during childhood or young adulthood. ${ }^{1)}$ LEATs comprise low-grade glial or glioneuronal tumors (GNTs) such as gangliogliomas (GGs), dysembryoplastic neuroepithelial tumors (DNTs), angiocentric astrocytomas, and isomorphic astrocytomas.

After leukemias, brain tumors are the most common tumors (20\%-22\%) in children. ${ }^{2)}$ Brain tumors are graded based on their histological appearance and molecular parameters. World Health Organization grades 1 and 2 are benign tumors, while grades 3 and 4 are malignant. Before biopsy or surgical resection, due to multiple and nonspecific clinical signs, tumor grade is mostly assumed based on analysis of tumor site and appearance on multiparametric magnetic resonance imaging (MRI). ${ }^{3)}$ For example, a hemorrhagic tumor with peripheral edema containing multiple ectatic vessels or a hypercellular tumor that is iso- or hypointense compared to the cortex on T2-weighted imaging is more suggestive of high-grade tumors. ${ }^{3-5)}$ Seizure prevalence is higher in slow-growing benign brain tumors, and some suggested explanations include: (1) longer life expectancy of patients with low-grade tumors contributing to increased seizure frequency; (2) insufficient time for cells of high-grade tumors to reorganize, vascularize, and develop mechanisms necessary for epileptogenesis; and (3) slow-growing tumor cells may possess intrinsic epileptogenic properties. ${ }^{6-8)}$

As the propensity for malignant progression is very low in LEATs, seizure control may be the main treatment target. Unfortunately, there is a high incidence of drug-resistant seizures among LEAT patients; consequently, although LEATs account for only $2 \%-5 \%$ of all brain tumors and are the etiology of seizures in only $1 \%-3 \%$ of pediatric epilepsy patients, LEATs are the second-most common reason for epilepsy surgery in children. ${ }^{9-12)}$ In a European study of brain specimens from 9,523 patients who underwent epilepsy surgery, the histopathologic etiology was identified as a tumor in $24 \%$ of all patients. LEATs comprised $82 \%$ of the tumors, and $84 \%$ of the LEATs were GGs or DNTs (Table 1).

LEATs are extremely responsive to surgical treatment, and more than $80 \%$ of patients achieve seizure freedom after surgery. ${ }^{13-16)}$ Therefore, epilepsy surgery should be considered a treatment option for LEATs. However, the optimal surgical timing remains controversial, and surgeries are often delayed (Table 1), mostly due to late referral after lengthy trials of antiepileptic drugs (AEDs), with a mean duration from seizure onset to surgery (i.e., duration of epilepsy) of more than 10 years. ${ }^{10}$ )

To help clinicians decide whether to pursue epilepsy surgery

Corresponding author: Joon Soo Lee, MD, PhD. Department of Pediatrics, Severance Children's Hospital, Yonsei University College of Medicine, 50-1 Yonsei-ro, Seodaemun-gu, Seoul 03722, Korea 
Table 1. Histopathological classification of 1,846 low-grade epilepsy-associated neuroepithelial tumors obtained from patients undergoing epilepsy surgery ${ }^{10)}$

\begin{tabular}{lccc} 
Tumor diagnosis & No. (\%) & $\begin{array}{c}\text { Age at seizure } \\
\text { onset (yr) }\end{array}$ & $\begin{array}{c}\text { Duration of } \\
\text { epilepsy (yr) }\end{array}$ \\
\hline GG & $986(53.6)$ & $12.1 \pm 10.3$ & $11.4 \pm 10.4$ \\
DNT & $565(30.6)$ & $14 \pm 10.9$ & $12 \pm 10.7$ \\
Pilocytic astrocytoma & $99(5.4)$ & $14.1 \pm 9.9$ & $12.3 \pm 11.4$ \\
PXA & $43(2.3)$ & $17.0 \pm 12.4$ & $12.8 \pm 12.1$ \\
Isomorphic astrocytoma & $17(0.9)$ & $16.0 \pm 14.3$ & $11.4 \pm 10.5$ \\
Gangliocytoma & $16(0.9)$ & $12.0 \pm 7.0$ & $17.1 \pm 12.4$ \\
Angiocentric glioma & $12(0.7)$ & $7.7 \pm 4.8$ & $6.9 \pm 6.0$ \\
Low-grade tumor, not specified & $108(5.9)$ & $14.6 \pm 13.2$ & $11.5 \pm 10.1$ \\
\hline Values are presented as number (\%) or mean \pm standard devaition. \\
GG, ganglioglioma; DNT, dysembryoplastic neuroepithelial tumor; PXA, \\
pleomorphic xanthoastrocytoma.
\end{tabular}

for LEATs, here we performed a systematic literature review of the factors associated with seizure and cognitive outcomes after epilepsy surgery for LEATs in children. Articles were extracted in July 2019 using PubMed searches of titles and abstracts with the following query terms: seizure or epilepsy; low-grade epilepsyassociated neuroepithelial tumor, long-term epilepsy-associated tumor, LEAT, ganglioglioma, dysembryoplastic neuroepithelial tumor, glioma, astrocytoma, xanthoastrocytoma, or tumor; surgery or resection; and child or pediatric. The inclusion criteria for the studies were: (1) epilepsy surgery in children with histopathologically confirmed LEATs, (2) seizure or epilepsy as the main symptom and reason for the surgery, and (3) mention of statistically significant predictive factors for seizure or cog. nitive outcomes. The exclusion criteria were: (1) inclusion of adults and children in the study and the reporting of data such that the child-specific data could not be distinguished from those for adults, (2) inclusion of high-grade tumors. Of $290 \mathrm{ex}$. tracted articles, 86 were excluded after initial screening due to irrelevancy, while an additional 186 were excluded after full article review due to ineligibility. Ultimately, 18 studies were included; of them, 16 addressed factors associated with seizure outcome, and 6 addressed factors associated with cognitive outcome. All included studies were retrospective.

\section{Epileptogenesis of LEATs}

The reason why almost all GNTs, including GGs and DNTs, cause seizures is not entirely understood, and various epileptogenic mechanisms of LEAT-associated epilepsy have been sug. gested. ${ }^{17)}$ The LEAT itself can be intrinsically epileptogenic due to the presence of hyperexcitable dysplastic neurons or a high neuronal density within the tumor as evidenced by various results from immunocytochemical studies, such as the high expression of glutamate receptor subtypes, downregulation of several gamma-aminobutyric acid (GABA) receptors, and deregulation of cation-chloride cotransporters. ${ }^{18-22)}$

LEATs can also invade normal tissues, altering neurotransmit- ter expression and inflammatory reactions. ${ }^{23)}$ For example, the deregulation of glutamate uptake and release by glutamate receptors on glial cells, which results in increased extracellular glutamate concentrations and decreased glial glutamate transporter expressions, has been observed. ${ }^{19,20,24,25)}$ LEATs have also been noted to activate the innate and adaptive immune systems. 26,27) Proinflammatory molecules increase neuronal excitability by enhancing extracellular glutamate concentrations and modifying the functions of glutamate and GABA receptors. ${ }^{28)}$ Immune system activation also causes upregulation of major histocompatibility complex class I molecules in neuronal cells and activates the mammalian target of rapamycin pathway. ${ }^{26,27,29)}$

Adjacent cortical areas can also undergo dysplastic reorganization, leading to hyperexcitability. ${ }^{30,31)}$ Studies have shown that the afferentiation of adjacent cortical regions can lead to denervation hypersensitivity, modified synchronization of local networks, and overexpression of neurotransmitters in adjacent cortical areas. ${ }^{7,23,32)}$

Other suggested mechanisms for LEAT-related seizures include blood-brain barrier dysfunction, altered gap junction channels in glial cells, alterations in the surrounding neuronal network, altered regional metabolism and $\mathrm{pH}$, regional hypoxic effects on the surrounding tissue, and an altered vascular supply. 7,18,33-39) Genetic predispositions for tumor-associated seizures have also been studied. ${ }^{7,40)}$ Therefore, the etiology of tumor-induced seizures is multifactorial and extends beyond the physical size of the tumor itself. ${ }^{41,42)}$

\section{Factors associated with seizure outcomes after epilepsy surgery for LEATs}

The following factors were mentioned at least once among the 16 studies that addressed seizure outcome as being predictive of seizure recurrence after surgery: younger age at seizure onset ${ }^{43)}$; older age at surgery ${ }^{44,45)}$; longer duration of epilepsy ${ }^{44,46)}$; greater number of AEDs taken at the time of surgery ${ }^{47}$; presence of generalized seizure ${ }^{48)}$; presence of generalized epileptiform discharges (EDs) in an electroencephalogram ${ }^{49}$; extratemporal or parietal location of the tumor ${ }^{45)}$; presence of satellite lesions on a MRI scan ${ }^{50}$; lesionectomy of temporal tumors ${ }^{43}$; and subtotal tumor resection. ${ }^{15,45,46,51-55)}$ The included studies that examined seizure outcome are summarized in Table 2, and more detailed information regarding the tumor types included, parameters for seizure outcome assessment, and factors irrelevant to seizure outcome are shown in Supplementary Table 1.

\section{Degree of tumor resection}

Gross total resection was the most frequently suggested favorable prognostic factor. ${ }^{15,45,46,49-55)}$ Fig. 1 shows an example of successful gross total resection of a LEAT (ganglioglioma) in a 7-year-old boy performed due to uncontrolled seizures after 
Table 2. Summary of articles addressing factors associated with seizure outcomes after epilepsy surgery for low-grade epilepsyassociated neuroepithelial tumors

\begin{tabular}{|c|c|c|c|}
\hline Study & $\begin{array}{l}\text { No. of } \\
\text { patients }\end{array}$ & $\begin{array}{l}\text { Seizure-free } \\
\text { rate }\end{array}$ & Factors associated with poor seizure outcome \\
\hline \multirow[t]{2}{*}{ Babini et al. $(2013)^{43)}$} & 30 & $86.7 \%$ & Younger age at seizure onset \\
\hline & & & Tailored surgery (i.e., extended resection for epileptogenic foci) for temporal lobe tumors \\
\hline Brahimaj et al. $(2014)^{47)}$ & 18 & $44.4 \%$ & Greater number of AEDs tried before surgery \\
\hline \multirow[t]{2}{*}{ Daszkiewicz et al. $(2018)^{44)}$} & 52 & $86.5 \%$ & Age of $>6$ yr at surgery \\
\hline & & & Duration of epilepsy $>1$ yr \\
\hline Ehrstedt et al. $(2017)^{51)}$ & 25 & $64.0 \%$ & Subtotal resection \\
\hline Faramand et al. $(2018)^{15)}$ & 92 & $80.4 \%$ & Subtotal resection \\
\hline Garc a-Fern ndez et al. (2011) $)^{52)}$ & 21 & $85.7 \%$ & Subtotal resection \\
\hline Khajavi et al. $(1995)^{53)}$ & 15 & $66.7 \%$ & Subtotal resection \\
\hline \multirow[t]{2}{*}{ Khajavi et al. (1999) ${ }^{46)}$} & 34 & $73.5 \%$ & Older age at surgery \\
\hline & & & Subtotal resection \\
\hline Ko et al. $(2019)^{54)}$ & 58 & $87.9 \%$ & Subtotal resection \\
\hline Minkin et al. $(2008)^{48)}$ & 24 & $83.3 \%$ & Presence of generalized seizure \\
\hline Nolan et al. $(2004)^{72)}$ & 26 & $84.6 \%$ & Subtotal resection \\
\hline Ogiwara et al. $(2010)^{66)}$ & 30 & $90.0 \%$ & None \\
\hline \multirow[t]{3}{*}{ Packer et al. (1994) } & 50 & $72.0 \%$ & Parietal location of tumor \\
\hline & & & Subtotal resection \\
\hline & & & Duration of epilepsy $>1 \mathrm{yr}$ \\
\hline Ramantani et al. (2014) ${ }^{55)}$ & 29 & $75.9 \%$ & Subtotal resection \\
\hline Uliel-Sibony et al. (2011) $)^{49)}$ & 41 & $82.9 \%$ & Presence of generalized EDs in an EEG \\
\hline Yang et al. $(2019)^{50)}$ & 39 & $66.7 \%$ & Presence of satellite lesions on an MRI scan \\
\hline
\end{tabular}

AED, antiepileptic drug; ED, epileptiform discharge; EEG, electroencephalogram; $M R I$, magnetic resonance imaging.

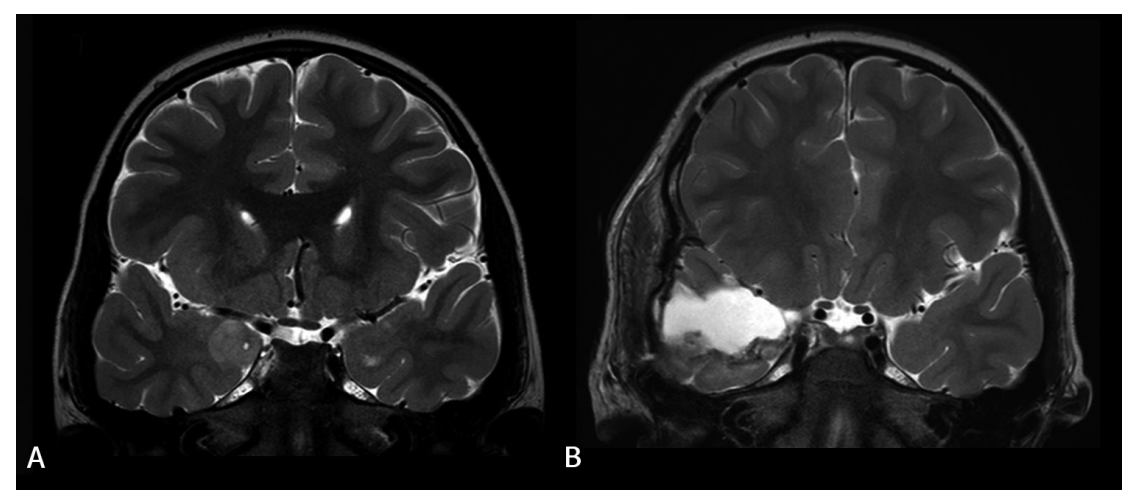

Fig. 1. Brain magnetic resonance image of a patient with a low-grade epilepsy-associated neuroepithelial tumor (ganglioglioma) before (A) and after (B) gross total resection.

he took 3 AEDs for 1.3 years. Several studies that included large numbers of patients confirmed that gross total resection is among the strongest factors leading to seizure freedom after LEAT resection. ${ }^{41,56-58)}$ However, some studies have stated otherwise. ${ }^{49,50,59,60)}$ Gross total resection may not be possible if the tumor is located adjacent to eloquent areas or other functional cortical areas. Nevertheless, gross total resection should be the goal of surgery, and efforts should be made using multimodal approaches to maximize the extent of resection.

\section{Duration of epilepsy}

Two studies mentioned that a longer duration of epilepsy was a poor prognostic factor for seizure outcomes. ${ }^{44,45)}$ The same has been demonstrated in previous systematic reviews that examined adults or both adults and children. ${ }^{56,57,61)}$ Early seizures may promote progressive changes in synaptic plasticity and cerebral blood flow, with prolonged epilepsy making surrounding neurons more epileptic; thus, seizure control can become more difficult once a period of time has elapsed following seizure onset. $^{56,62-65)}$ However, 8 studies found that epilepsy duration is not predictive of seizure outcome, ${ }^{15,43,46,49-52,55)}$ while 2 studies suggested otherwise. Thus, more studies are needed to draw a definitive conclusion. 


\section{Age at surgery}

Two studies found that an older age at surgery is predictive for persistent seizures, ${ }^{44,46)}$ whereas 9 studies found no association between age at surgery and seizure outcome. $15,43,45,47,48,50,52$, $54,55,66)$ In an Italian nationwide study of epilepsy surgery for LEATs that included a total of 282 adults and children, older age at surgery was the most significant predictor of persistent seizures, with a $4 \%$ increase in the probability of an unfavorable outcome for every year waited. ${ }^{16)}$ Since previous studies demonstrated no significant difference in surgical outcome between pediatric and adult patients with LEATs, ${ }^{16,56}$ the reason for the poor prognosis associated with older age at surgery may be the duration of epilepsy rather than the patient's age itself.

\section{Extent of resection}

One article suggested that extended resection (i.e., removal of the tumor and surrounding epileptogenic zone) is helpful for achieving seizure freedom, ${ }^{43)}$ whereas 6 other articles found no difference in seizure outcomes between lesionectomy alone and extended resection. ${ }^{46,47,49,52,53,66)}$ Thus, the matter of surgical strategy remains controversial. The discordance among previous studies also raises an important question regarding the use of additional corticectomy or additional amygdalohippocampectomy for temporal lobe tumors. ${ }^{14,16,23,56,60,67-69)}$ Extended resections are mainly performed for temporal tumors, while there is a lack of reports detailing outcomes for extratemporal tumors. ${ }^{43,67,69-71)}$ One indicator that endorses the application of extended tailored resection is the presence of adjacent dual pathology, such as focal cortical dysplasia or hippocampal sclerosis, that can cause seizures after lesionectomy. ${ }^{56)}$ Therefore, what can currently be said with confidence is that extended resection may be considered, particularly when treating temporal tumors with evidence of dual pathology. ${ }^{56}$

\section{Utilization of intraoperative electrocortico- graphy}

Intraoperative electrocorticography (ECoG) or 2-stage surgery is performed when delineation of the epileptogenic zone is needed due to the presence of multifocal epileptogenic foci or a tumor location adjacent to functional areas. All 3 studies that investigated the association between the utilization of intraoperative ECoG and seizure outcome found that it is not related to higher rates of seizure freedom. ${ }^{49,66,72)}$ Other large reviews reported the same conclusion. However, caution must be taken when interpreting these results, as intraoperative ECoG is more likely to be used in more difficult cases that involve multifocal epileptogenic foci or tumors located near eloquent areas. $^{56,57)}$ Other studies advocate for the utilization of intraoperative ECoG during tailored surgery. ${ }^{73-76)}$ Therefore, the use of intraoperative ECoG is advised when extended resection is anticipated. ${ }^{73)}$

\section{Factors associated with cognitive outcome after epilepsy surgery for LEATs}

Studies that addressed factors associated with preoperative fullscale intelligence quotient (FSIQ), longer duration of epilepsy, and younger age at seizure onset are universally mentioned as poor prognostic factors for preoperative FSIQ. ${ }^{15,16,52,54,55)}$ An explanation of this finding is reduced brain plasticity and a limited degree of possible postoperative cognitive gains. ${ }^{77,78)}$ The studies addressing cognitive outcome are summarized in Table 3, and more detailed information regarding the cognitive parameters is shown in Supplementary Table 2.

Postoperative cognitive function has been shown to significantly depend on preoperative cognitive function. ${ }^{15,54,55)}$ GarcíaFernández et al. ${ }^{52)}$ reported that none of the various cognitive domains of a postoperative neuropsychological test performed 1 year after resection showed significant decline; on the contrary, there were statistically significant improvements in several cog. nitive domains (Supplementary Table 2). Ramantani et al. ${ }^{55}$ ) also reported that, at the group level, there was significant intraindividual improvement in verbal intelligence quotient (IQ) and performance IQ as well as a trend toward FSIQ improvement after epilepsy surgery. Finally, a study by Faramand et al. ${ }^{15)}$ showed that postoperative FSIQ improved in $61 \%$ of children, declined in $36.5 \%$ of children, and was unchanged in $2.5 \%$ of children. The study by García-Fernández et al. ${ }^{52)}$ mentioned above also showed poorer preoperative cognitive function in children with drug-resistant epilepsy, suggesting that it can be beneficial for surgery to occur before drug-resistant epilepsy develops.

Overall, earlier surgery can prevent low postoperative FSIQ in children, particularly young children, and that improved cognitive function can be expected following epilepsy surgery.

\section{Conclusion}

LEATs usually develop in children and young adults who present with seizures that are highly drug-resistant. Surgical treatment, however, is extremely effective, resulting in seizure freedom in approximately 70\%-80\% of cases. The achievement of gross total resection may be the most important prognostic factor for seizure freedom. Shorter duration of epilepsy, younger age at surgery, and extended resection of temporal lobe tumors have also been suggested as favorable prognostic factors for seizure control.

Poor cognitive function in children with LEATs is strongly associated with longer duration of epilepsy and younger age at seizure onset. Therefore, surgical treatment should be considered as an early option in children with LEATs prior to the diagnosis of drug-resistant epilepsy to protect the cognitive 
Table 3. Summary of articles addressing factors associated with cognitive outcomes after epilepsy surgery for low-grade epilepsyassociated neuroepithelial tumors

\begin{tabular}{|c|c|c|c|c|}
\hline Study & $\begin{array}{l}\text { No. of } \\
\text { patients }\end{array}$ & Parameters & Value & $\begin{array}{l}\text { Factors associated with } \\
\text { poor cognitive outcome }\end{array}$ \\
\hline \multirow[t]{3}{*}{ Faramand et al. $(2018)^{15)}$} & 22 & Postoperative FSIQ & Seizure-free $(n=14): 92.4$ (range, 73-116) & Younger age at seizure onset \\
\hline & & & Low seizure severity $(n=5): 105.0$ (range, 71-126) & Persistent seizure after surgery \\
\hline & & & High seizure severity $(n=3): 75.3$ (range, 70-80) & High seizure severity after surgery \\
\hline \multirow[t]{3}{*}{ Faramand et al. $(2018)^{15)}$} & 90 & Preoperative FSIQ & $81($ IQR, 71-95) & Younger age at seizure onset \\
\hline & & & & Longer duration of epilepsy \\
\hline & 41 & Postoperative FSIQ & $86(I Q R, 71-100)$ & Low preoperative FSIQ \\
\hline \multirow{3}{*}{$\begin{array}{l}\text { García-Fernández et al. } \\
(2011)^{52)}\end{array}$} & 21 & Preoperative FSIQ & $85.2 \pm 21.9$ & Younger age at seizure onset \\
\hline & & & & Drug-resistant epilepsy before surgery \\
\hline & & Postoperative FSIQ & $88.6 \pm 17.7$ & None \\
\hline Giulioni et al. (2017) ${ }^{16)}$ & Unknown & Preoperative NP test & Normal vs. pathologic (deficit) & Longer duration of epilepsy \\
\hline \multirow[t]{2}{*}{ Ko et al. $(2019)^{54)}$} & 58 & Preoperative FSIQ & $78.9 \pm 27.1$ & Longer duration of epilepsy \\
\hline & 42 & Postoperative FSIQ & $80.9 \pm 28.7$ & Low preoperative FSIQ \\
\hline \multirow[t]{4}{*}{ Ramantani et al. $(2014)^{55)}$} & 25 & Preoperative FSIQ & $93.0 \pm 21.8$ & Longer duration of epilepsy \\
\hline & & Preoperative VIQ & $95.9 \pm 13.8$ & Longer duration of epilepsy \\
\hline & & Preoperative PIQ & $101.2 \pm 15.5$ & Younger age at seizure onset \\
\hline & 24 & Postoperative FSIQ & $91.7 \pm 21.6$ & Low preoperative FSIQ \\
\hline
\end{tabular}

Values are presented as mean (range), median (interquartile range), or mean \pm standard deviation.

$F S I Q$, full-scale intelligence quotient; $N P$, neuropsychological; VIQ, verbal intelligence quotient; $P I Q$, performance intelligence quotient.

function of LEAT patients by averting recurrent seizures and the administration of multiple AEDs.

\section{Conflicts of interest}

No potential conflict of interest relevant to this article was reported.

Supplementary materials

Supplementary Tables 1 and 2 can be found via https://doi. org/10.3345/kjp.2019.01151.

\section{References}

1. Holthausen H, Blümcke I. Epilepsy-associated tumours: what epileptologists should know about neuropathology, terminology, and classification systems. Epileptic Disord 2016;18:240-51.

2. Bauchet L, Rigau V, Mathieu-Daudé H, Fabbro-Peray P, Palenzuela G, Figarella-Branger D, et al. Clinical epidemiology for childhood primary central nervous system tumors. J Neurooncol 2009;92:87-98.

3. Koob M, Girard N. Cerebral tumors: specific features in children. Diagn Interv Imaging 2014;95:965-83.

4. Porto L, Jurcoane A, Schwabe D, Hattingen E. Conventional magnetic resonance imaging in the differentiation between high and low-grade brain tumours in paediatric patients. Eur J Paediatr Neurol 2014;18:25-9.

5. Forbes JA, Chambless LB, Smith JG, Wushensky CA, Lebow RL, Alvarez $\mathrm{J}$, et al. Use of T2 signal intensity of cerebellar neoplasms in pediatric patients to guide preoperative staging of the neuraxis. J Neurosurg Pediatr 2011;7:165-74

6. Chen DY, Chen CC, Crawford JR, Wang SG. Tumor-related epilepsy: epidemiology, pathogenesis and management. J Neurooncol 2018;139: 13-21.

7. van Breemen MS, Wilms EB, Vecht CJ. Epilepsy in patients with brain tumours: epidemiology, mechanisms, and management. Lancet Neurol 2007;6:421-30.

8. Hildebrand J, Lecaille C, Perennes J, Delattre JY. Epileptic seizures during follow-up of patients treated for primary brain tumors. Neurology 2005;
65:212-5.

9. Harvey AS, Cross JH, Shinnar S, Mathern GW; ILAE Pediatric Epilepsy Surgery Survey Taskforce. Defining the spectrum of international practice in pediatric epilepsy surgery patients. Epilepsia 2008;49:146-55.

10. Blumcke I, Spreafico R, Haaker G, Coras R, Kobow K, Bien CG, et al. Histopathological findings in brain tissue obtained during epilepsy surgery. NEngl J Med 2017;377:1648-56.

11. Jemal A, Siegel R, Ward E, Murray T, Xu J, Smigal C, et al. Cancer statistics, 2006. CA Cancer J Clin 2006;56:106-30.

12. Ullrich NJ, Pomeroy SL, Kapur K, Manley PE, Goumnerova LC, Loddenkemper T. Incidence, risk factors, and longitudinal outcome of seizures in long-term survivors of pediatric brain tumors. Epilepsia 2015;56:1599604.

13. Chan CH, Bittar RG, Davis GA, Kalnins RM, Fabinyi GC. Long-term seizure outcome following surgery for dysembryoplastic neuroepithelial tumor. J Neurosurg 2006;104:62-9.

14. Giulioni M, Gardella E, Rubboli G, Roncaroli F, Zucchelli M, Bernardi B, et al. Lesionectomy in epileptogenic gangliogliomas: seizure outcome and surgical results. J Clin Neurosci 2006;13:529-35.

15. Faramand AM, Barnes N, Harrison S, Gunny R, Jacques T, Tahir MZ, et al. Seizure and cognitive outcomes after resection of glioneuronal tumors in children. Epilepsia 2018;59:170-8.

16. Giulioni M, Marucci G, Pelliccia V, Gozzo F, Barba C, Didato G, et al. Epilepsy surgery of "low grade epilepsy associated neuroepithelial tumors": a retrospective nationwide Italian study. Epilepsia 2017;58: 183241.

17. Aronica E, Crino PB. Epilepsy related to developmental tumors and malformations of cortical development. Neurotherapeutics 2014;11:25168.

18. Wolf HK, Birkholz T, Wellmer J, Blümcke I, Pietsch T, Wiestler OD. Neurochemical profile of glioneuronal lesions from patients with pharmacoresistant focal epilepsies. J Neuropathol Exp Neurol 1995;54:689-97.

19. Wolf HK, Buslei R, Blümcke I, Wiestler OD, Pietsch T. Neural antigens in oligodendrogliomas and dysembryoplastic neuroepithelial tumors. Acta Neuropathol 1997;94:436-43.

20. Aronica E, Yankaya B, Jansen GH, Leenstra S, van Veelen CW, Gorter JA, et al. Ionotropic and metabotropic glutamate receptor protein expression in glioneuronal tumours from patients with intractable epilepsy. Neuropathol Appl Neurobiol 2001;27:223-37.

21. Fassunke J, Majores M, Tresch A, Niehusmann P, Grote A, Schoch S, et 
al. Array analysis of epilepsy-associated gangliogliomas reveals expression patterns related to aberrant development of neuronal precursors. Brain 2008;131(Pt 11):3034-50.

22. Aronica E, Boer K, Redeker S, Spliet WG, van Rijen PC, Troost D, et al. Differential expression patterns of chloride transporters, $\mathrm{Na}+-\mathrm{K}+-$ 2Cl--cotransporter and $\mathrm{K}+$-Cl--cotransporter, in epilepsy-associated malformations of cortical development. Neuroscience 2007;145:185-96.

23. Zaghloul KA, Schramm J. Surgical management of glioneuronal tumors with drug-resistant epilepsy. Acta Neurochir (Wien) 2011;153:1551-9.

24. Seifert G, Carmignoto G, Steinhäuser C. Astrocyte dysfunction in epilepsy. Brain Res Rev 2010;63:212-21.

25. Ye ZC, Rothstein JD, Sontheimer H. Compromised glutamate transport in human glioma cells: reduction-mislocalization of sodium-dependent glutamate transporters and enhanced activity of cystine-glutamate exchange. J Neurosci 1999; 19:10767-77.

26. Aronica E, Gorter JA, Redeker S, Ramkema M, Spliet WG, van Rijen PC, et al. Distribution, characterization and clinical significance of microglia in glioneuronal tumours from patients with chronic intractable epilepsy. Neuropathol Appl Neurobiol 2005;31:280-91.

27. Prabowo AS, Iyer AM, Anink JJ, Spliet WG, van Rijen PC, Aronica E. Differential expression of major histocompatibility complex class I in developmental glioneuronal lesions. J Neuroinflammation 2013;10:12.

28. Vezzani A, French J, Bartfai T, Baram TZ. The role of inflammation in epilepsy. Nat Rev Neurol 2011;7:31-40.

29. Boer K, Troost D, Timmermans W, van Rijen PC, Spliet WG, Aronica E. Pi3K-mTOR signaling and AMOG expression in epilepsy-associated glioneuronal tumors. Brain Pathol 2010;20:234-44.

30. Rajneesh KF, Binder DK. Tumor-associated epilepsy. Neurosurg Focus 2009;27:E4.

31. Rudà R, Trevisan E, Soffietti R. Epilepsy and brain tumors. Curr Opin Oncol 2010;22:611-20.

32. Bartolomei F, Bosma I, Klein M, Baayen JC, Reijneveld JC, Postma TJ, et al. How do brain tumors alter functional connectivity? A magnetoencephalography study. Ann Neurol 2006;59:128-38.

33. Steinhäuser C, Seifert G. Glial membrane channels and receptors in epilepsy: impact for generation and spread of seizure activity. Eur J Pharmacol 2002;447:227-37.

34. Aronica E, Gorter JA, Jansen GH, Leenstra S, Yankaya B, Troost D. Expression of connexin 43 and connexin 32 gap-junction proteins in epilepsy-associated brain tumors and in the perilesional epileptic cortex. Acta Neuropathol 2001;101:449-59.

35. Schmitz AK, Grote A, Raabe A, Urbach H, Friedman A, von Lehe M, et al. Albumin storage in neoplastic astroglial elements of gangliogliomas. Seizure 2013;22:144-50.

36. Alkonyi B, Mittal S, Zitron I, Chugani DC, Kupsky WJ, Muzik O, et al. Increased tryptophan transport in epileptogenic dysembryoplastic neuroepithelial tumors. J Neurooncol 2012;107:365-72.

37. Calatozzolo C, Pollo B, Botturi A, Dinapoli L, Carosi M, Salmaggi A, et al. Multidrug resistance proteins expression in glioma patients with epilepsy. J Neurooncol 2012;110:129-35.

38. You G, Sha Z, Jiang T. The pathogenesis of tumor-related epilepsy and its implications for clinical treatment. Seizure 2012;21:153-9.

39. Shamji MF, Fric-Shamji EC, Benoit BG. Brain tumors and epilepsy: pathophysiology of peritumoral changes. Neurosurg Rev 2009;32:27584.

40. Berntsson SG, Malmer B, Bondy ML, Qu M, Smits A. Tumor-associated epilepsy and glioma: are there common genetic pathways? Acta Oncol 2009;48:955-63.

41. Ranger A, Diosy D. Seizures in children with dysembryoplastic neuroepithelial tumors of the brain--A review of surgical outcomes across several studies. Childs Nerv Syst 2015;31:847-55.

42. Lee JW, Wen PY, Hurwitz S, Black P, Kesari S, Drappatz J, et al. Morphological characteristics of brain tumors causing seizures. Arch Neurol 2010;67:336-42.

43. Babini M, Giulioni M, Galassi E, Marucci G, Martinoni M, Rubboli G, et al. Seizure outcome of surgical treatment of focal epilepsy associated with low-grade tumors in children. J Neurosurg Pediatr 2013;11:214-23.
44. Daszkiewicz P, Kowalczyk P, Roszkowski M. Surgical treatment of neuronal-glial tumors of mesial-basal part of temporal lobe: Long term outcome and control of epilepsy in pediatric patients. Neurol Neurochir Pol 2018;52:2-8.

45. Packer RJ, Sutton LN, Patel KM, Duhaime AC, Schiff S, Weinstein SR, et al. Seizure control following tumor surgery for childhood cortical lowgrade gliomas. J Neurosurg 1994;80:998-1003.

46. Khajavi K, Comair YG, Wyllie E, Palmer J, Morris HH, Hahn JF. Surgical management of pediatric tumor-associated epilepsy. J Child Neurol 1999; 14:15-25.

47. Brahimaj B, Greiner HM, Leach JL, Horn PS, Stevenson CB, Miles L, et al. The surgical management of pediatric brain tumors causing epilepsy: consideration of the epileptogenic zone. Childs Nerv Syst 2014;30:138391.

48. Minkin K, Klein O, Mancini J, Lena G. Surgical strategies and seizure control in pediatric patients with dysembryoplastic neuroepithelial tumors: a single-institution experience. J Neurosurg Pediatr 2008;1:20610.

49. Uliel-Sibony S, Kramer U, Fried I, Fattal-Valevski A, Constantini S. Pediatric temporal low-grade glial tumors: epilepsy outcome following resection in 48 children. Childs Nerv Syst 2011;27:1413-8.

50. Yang J, Kim SK, Kim KJ, Chae JH, Lim BC, Wang KC, et al. Satellite lesions of DNET: implications for seizure and tumor control after resection. J Neurooncol 2019;143:437-45.

51. Ehrstedt C, Moreira NC, Casar-Borota O, Strömberg B, Ahlsten G. Glioneuronal tumors in childhood - Before and after surgery. A long-term follow-up study. Epilepsy Behav 2017;72:82-8.

52. García-Fernández M, Fournier-Del Castillo C, Ugalde-Canitrot A, PérezJiménez Á, Álvarez-Linera J, De Prada-Vicente I, et al. Epilepsy surgery in children with developmental tumours. Seizure 2011;20:616-27.

53. Khajavi K, Comair YG, Prayson RA, Wyllie E, Palmer J, Estes ML, et al. Childhood ganglioglioma and medically intractable epilepsy. A clinicopathological study of 15 patients and a review of the literature. Pediatr Neurosurg 1995;22:181-8.

54. Ko A, Kim SH, Kim SH, Park EK, Shim KW, Kang HC, et al. Epilepsy surgery for children with low-grade epilepsy-associated tumors: factors associated with seizure recurrence and cognitive function. Pediatr Neurol 2019;91:50-6.

55. Ramantani G, Kadish NE, Anastasopoulos C, Brandt A, Wagner K, Strobl $\mathrm{K}$, et al. Epilepsy surgery for glioneuronal tumors in childhood: avoid loss of time. Neurosurgery 2014;74:648-57.

56. Englot DJ, Berger MS, Barbaro NM, Chang EF. Factors associated with seizure freedom in the surgical resection of glioneuronal tumors. Epilepsia 2012;53:51-7.

57. Englot DJ, Berger MS, Barbaro NM, Chang EF. Predictors of seizure freedom after resection of supratentorial low-grade gliomas. A review. J Neurosurg 2011;115:240-4.

58. Southwell DG, Garcia PA, Berger MS, Barbaro NM, Chang EF. Longterm seizure control outcomes after resection of gangliogliomas. Neurosurgery 2012;70:1406-13.

59. Kirkpatrick PJ, Honavar M, Janota I, Polkey CE. Control of temporal lobe epilepsy following en bloc resection of low-grade tumors. J Neurosurg 1993;78:19-25.

60. Blümcke I, Wiestler OD. Gangliogliomas: an intriguing tumor entity associated with focal epilepsies. J Neuropathol Exp Neurol 2002;61:57584.

61. Yang I, Chang EF, Han SJ, Barry JJ, Fang S, Tihan T, et al. Early surgical intervention in adult patients with ganglioglioma is associated with improved clinical seizure outcomes. J Clin Neurosci 2011;18:29-33.

62. Blume WT. The progression of epilepsy. Epilepsia 2006;47 Suppl 1:71-8.

63. Breier JI, Mullani NA, Thomas AB, Wheless JW, Plenger PM, Gould KL, et al. Effects of duration of epilepsy on the uncoupling of metabolism and blood flow in complex partial seizures. Neurology 1997;48:1047-53.

64. Ben-Ari Y, Dudek FE. Primary and secondary mechanisms of epileptogenesis in the temporal lobe: there is a before and an after. Epilepsy Curr 2010;10:118-25.

65. Hauser WA, Lee JR. Do seizures beget seizures? Prog Brain Res 2002; 
135:215-9.

66. Ogiwara H, Nordli DR, DiPatri AJ, Alden TD, Bowman RM, Tomita T. Pediatric epileptogenic gangliogliomas: seizure outcome and surgical results. J Neurosurg Pediatr 2010;5:271-6.

67. Giulioni M, Rubboli G, Marucci G, Martinoni M, Volpi L, Michelucci $\mathrm{R}$, et al. Seizure outcome of epilepsy surgery in focal epilepsies associated with temporomesial glioneuronal tumors: lesionectomy compared with tailored resection. J Neurosurg 2009;111:1275-82.

68. Pelliccia V, Deleo F, Gozzo F, Sartori I, Mai R, Cossu M, et al. Early and late epilepsy surgery in focal epilepsies associated with long-term epilepsyassociated tumors. J Neurosurg 2017; 127:1147-52.

69. Cossu M, Fuschillo D, Bramerio M, Galli C, Gozzo F, Pelliccia V, et al. Epilepsy surgery of focal cortical dysplasia-associated tumors. Epilepsia 2013;54 Suppl 9:115-22.

70. Giulioni M, Marucci G, Martinoni M, Volpi L, Riguzzi P, Marliani AF, et al. Seizure outcome in surgically treated drug-resistant mesial temporal lobe epilepsy based on the recent histopathological classifications. J Neurosurg 2013;119:37-47.

71. Bonney PA, Glenn CA, Ebeling PA, Conner AK, Boettcher LB, Cameron $\mathrm{DM}$, et al. Seizure freedom rates and prognostic indicators after resection of gangliogliomas: a review. World Neurosurg 2015;84:1988-96.

72. Nolan MA, Sakuta R, Chuang N, Otsubo H, Rutka JT, Snead OC 3rd, et al. Dysembryoplastic neuroepithelial tumors in childhood: long-term outcome and prognostic features. Neurology 2004;62:2270-6.

73. Santos MV, de Oliveira RS, Machado HR. Approach to cortical dysplasia associated with glial and glioneuronal tumors (FCD type IIIb). Childs Nerv Syst 2014;30:1869-74.

74. Lombardi D, Marsh R, de Tribolet N. Low grade glioma in intractable epilepsy: lesionectomy versus epilepsy surgery. Acta Neurochir Suppl 1997;68:70-4.

75. Qiu B, Ou S, Song T, Hu J, You L, Wang Y, et al. Intraoperative electrocorticography-guided microsurgical management for patients with onset of supratentorial neoplasms manifesting as epilepsy: a review of 65 cases. Epileptic Disord 2014;16:175-84.

76. Sugano H, Shimizu H, Sunaga S. Efficacy of intraoperative electrocorticography for assessing seizure outcomes in intractable epilepsy patients with temporal-lobe-mass lesions. Seizure 2007;16:120-7.

77. O'Leary DS, Lovell MR, Sackellares JC, Berent S, Giordani B, Seidenberg $\mathrm{M}$, et al. Effects of age of onset of partial and generalized seizures on neuropsychological performance in children. J Nerv Ment Dis 1983; 171:624-9.

78. Vendrame M, Alexopoulos AV, Boyer K, Gregas M, Haut J, Lineweaver $\mathrm{T}$, et al. Longer duration of epilepsy and earlier age at epilepsy onset correlate with impaired cognitive development in infancy. Epilepsy Behav 2009;16:431-5. 


\begin{tabular}{|c|c|c|c|c|c|}
\hline Study & $\begin{array}{l}\text { No. of } \\
\text { patients }\end{array}$ & Types of tumor (percent) & Parameters for seizure outcome & $\begin{array}{l}\text { Factors associated with } \\
\text { poor seizure outcome }\end{array}$ & Factors irrelevant to seizure outcome \\
\hline $\begin{array}{l}\text { Babini et al. } \\
\text { (2013) }\end{array}$ & 30 & $\begin{array}{l}\text { GG }(66.7 \%), \text { DNT (13.3\%), PXA (6.7\%), } \\
\text { Gangliocytoma (3.3\%), Angiocentric } \\
\text { glioma (3.3\%), Papillary GNT (3.3\%), } \\
\text { Extraventricular neurocytoma (3.3\%) }\end{array}$ & $\begin{array}{l}\text { Good: Engel class I }(n=26,86.7 \%) \\
\text { Poor: Engel class }\|-\| I(n=4,13.3 \%) \text {, } \\
\text { at last } f / u \text {, f/u duration of mean } 7.1 \text { years (range, 1-17 } \\
\text { years) }\end{array}$ & $\begin{array}{l}\text { Younger age at sz onset } \\
\leq 4 \text { years at sz onset } \\
\text { Tailored surgery in temporal lobe } \\
\text { tumors }\end{array}$ & $\begin{array}{l}\text { Age at surgery, duration of epilepsy, secondary } \\
\text { generalization, sz frequency before surgery, location of } \\
\text { tumor, side of tumor location }\end{array}$ \\
\hline $\begin{array}{l}\text { Brahimaj et al. } \\
(2014)\end{array}$ & 18 & $\begin{array}{l}\text { DNT (27.8\%), PXA (16.7\%), GG (11.1\%), } \\
\text { Desmoplastic GG (11.1\%), Low-grade } \\
\text { glioma (11.1\%), Pilocytic astrocytoma } \\
\text { (11.1\%), Oligodendroglioma (5.6\%), } \\
\text { Fibrillary astrocytoma (5.6\%) }\end{array}$ & $\begin{array}{l}\text { Good: } \mathrm{sz} \text { free }(\mathrm{n}=8,44.4 \%) \\
\text { Poor: persistent } \mathrm{sz}(\mathrm{n}=10,55.6 \%), \\
\text { at last f/u, mean f/u duration of } 39 \text { months (minimum, } \\
6 \text { months) }\end{array}$ & $\begin{array}{l}\text { Greater number of AEDs tried } \\
\text { before surgery }\end{array}$ & $\begin{array}{l}\text { Age at sz onset, age at surgery, gender, contralateral ED } \\
\text { on EEG, extent of resection }\end{array}$ \\
\hline $\begin{array}{l}\text { Daszkiewicz et } \\
\text { al. (2018) }\end{array}$ & 52 & $\begin{array}{l}\text { GG }(92.3 \%) \text {, DNT }(7.7 \%) \text { (tumors } \\
\text { located in mesial-basal part of the } \\
\text { temporal lobe were included) }\end{array}$ & $\begin{array}{l}\text { Good: Engel class I }(n=45,86.5 \%) \\
\text { Poor: Engel class } \|-11 \mid(n=7,13.5 \%), \\
\text { at last } f / u, f / u \text { duration of mean } 2.9 \text { years (range, 1-7 } \\
\text { years) }\end{array}$ & $\begin{array}{l}\text { Age }>6 \text { years at surgery } \\
\text { Duration of epilepsy }>1 \text { year }\end{array}$ & $\begin{array}{l}\text { Extent of tumor, coexistence of cortical dysplasia, surgical } \\
\text { approach, extent or resection }\end{array}$ \\
\hline $\begin{array}{l}\text { Ehrstedt et al. }{ }^{a)} \\
(2017)\end{array}$ & 25 & $\begin{array}{l}\text { GG, DNT, Infantile desmoplastic GG } \\
\text { (proportions unknown) }\end{array}$ & $\begin{array}{l}\text { Good: Engel class I }(n=45,86.5 \%) \\
\text { Poor: Engel class II-III }(n=7,13.5 \%) \text {, } \\
\text { at last } f / u, f / u \text { duration of mean } 2.9 \text { years (range, 1-7 } \\
\text { years) }\end{array}$ & STR & $\begin{array}{l}\text { Age at sz onset, gender, duration of epilepsy, drug- } \\
\text { resistant epilepsy before surgery, tumor location }\end{array}$ \\
\hline $\begin{array}{l}\text { Faramand et al. } \\
\text { (2017) }\end{array}$ & 92 & $\begin{array}{l}\text { DNT, GG, Demoplastic GG, Angiocentric } \\
\text { glioma, GNT not specified (proportions } \\
\text { unknown) }\end{array}$ & $\begin{array}{l}\text { Good: Engel class I }(n=74,80.4 \%) \\
\text { Poor: Engel class } \|-I V(n=18,19.6 \%) \\
\text { at last } f / u, f / u \text { duration of } \geq 12 \text { months }\end{array}$ & STR & $\begin{array}{l}\text { Age at sz onset, age at first assessment, age at surgery, } \\
\text { gender, duration of epilepsy, secondary generalization, } \\
\text { tumor location, side of tumor location, tumor type }\end{array}$ \\
\hline $\begin{array}{l}\text { García- } \\
\text { Fernández et } \\
\text { al. (2011) }\end{array}$ & 21 & $\begin{array}{l}\text { GG (47.6\%), DNT (42.9\%), Gangliocyto- } \\
\text { ma (9.5\%) }\end{array}$ & $\begin{array}{l}\text { Good: } s z \text { free }(n=18,85.7 \%) \\
\text { Poor: persistent } s z(n=3,14.3 \%), \\
\text { at last } f / u, f / u \text { duration of mean } 4.68 \text { years (SD, 2.13; } \\
\text { minimum, } 1 \text { year) }\end{array}$ & STR & $\begin{array}{l}\text { Age at sz onset, age at surgery, duration of epilepsy, } \\
\text { tumor location, side of tumor location, type of } \\
\text { tumor, drug-resistant epilepsy, number of interictal } \\
\text { epileptogenic foci on EEG, interictal ED on EEG, extent } \\
\text { of resection }\end{array}$ \\
\hline Khajavi et al. & 15 & GG (100\%) & Good: sz free or $\geq 90 \%$ sz reduction $(n=12,80.0 \%$ ) & STR & Extended resection of epileptogenic foci utilizing iEEG \\
\hline
\end{tabular}

Poor: $<90 \%$ sz reduction $(n=3,20.0 \%)$

at last $\mathrm{f} / \mathrm{u}$, f/u duration mean 42 months (range, 18-107 months)

\begin{tabular}{|c|c|c|c|c|}
\hline $\begin{array}{l}\text { Khajavi et al. } \\
\text { (1999) }\end{array}$ & 34 & $\begin{array}{l}\text { GG }(44.1 \%), \text { DNT (20.6\%), Low-grade } \\
\text { astrocytoma (20.6\%), Oligodendro- } \\
\text { glioma (11.8\%), Mixed glioma (2.9\%) }\end{array}$ & $\begin{array}{l}\text { Good: } s z \text { free or } \geq 90 \% \text { sz reduction }(n=29,85.3 \%) \\
\text { Poor: }<90 \% \text { sz reduction }(n=5,14.7 \%) \text {, } \\
\text { at last } f / u \text {, f/u duration mean } 43 \text { months (range, } \\
18-126 \text { months) }\end{array}$ & $\begin{array}{l}\text { Older age at surgery } \\
\text { STR }\end{array}$ \\
\hline Ko et al. (2019) & 58 & $\begin{array}{l}\text { GG }(46.6 \%), \text { DNT }(48.3 \%) \text {, Pilocytic } \\
\text { astrocytoma (3.4\%), Papillary glioneu- } \\
\text { ronal tumor (1.7\%) }\end{array}$ & $\begin{array}{l}\text { Good: sz free }(n=51,87.9 \%) \\
\text { Poor: persistent } s z(n=7,12.1 \%) \text {, } \\
\text { at last } f / u, f / u \text { duration of median } 5.6 \text { years (IQR, } \\
\text { 3.2-10.0; minimum, } 2 \text { years) }\end{array}$ & $\begin{array}{l}\text { Univariate: } \\
\text {-Longer duration of epilepsy } \\
\text {-Greater number of AEDs taken } \\
\text { before surgery } \\
\text {-STR } \\
\text {-Temporal location of tumor } \\
\text { Multivariate: } \\
\text {-STR }\end{array}$ \\
\hline
\end{tabular}

$\begin{array}{lll}\begin{array}{c}\text { Minkin et al. } \\ (2008)\end{array} & 24 & \text { DNT (100\%) } \\ \begin{array}{c}\text { Nolan et al. } \\ (2004)\end{array} & 26 & \text { DNT (100\%) }\end{array}$

Good: Engel class I ( $n=20,83.3 \%)$

Presence of generalized sz

uration of epilepsy, sz frequency before surgery, tumor type, location of tumor,

at last $f / u$, f/u duration of mean 6.7 years (range, 1-16

years)

Good: sz free $(n=22,84.6 \%)$

Poor: persistent sz ( $\mathrm{n}=4,15.4 \%$ )

at 12 months after surgery

Duration of epilepsy $>2$ years

Age at surgery $>10$ years

STR

Good: sz free ( $n=16,61.5 \%)$

STR

Poor: persistent $\mathrm{sz}(\mathrm{n}=10,38.5 \%)$

at last $f / u$, f/u duration of mean 4.3 years (SD, 2.5

range, $1-11$ years)

\begin{tabular}{|c|c|c|}
\hline $\begin{array}{l}\text { Ogiwara et al. } \\
(2010)\end{array}$ & 30 & GG (100\%) \\
\hline \multirow[t]{2}{*}{$\begin{array}{l}\text { Packer et al. } \\
\text { (1994) }\end{array}$} & $\begin{array}{l}60(\geq 1 \mathrm{sz} \\
\text { before } \\
\text { surgery) }\end{array}$ & \multirow[t]{2}{*}{$\begin{array}{l}\text { GG }(68.3 \%), \text { Low-grade glioma (18.3\%) } \\
\text { PXA (6.7\%), Intermediate-grade } \\
\text { glioma (3.3\%), Mixed low-grade } \\
\text { glioma (3.3\%) }\end{array}$} \\
\hline & $\begin{array}{l}50 \text { ( } \geq 5 \mathrm{sz} \\
\text { before } \\
\text { surgery) }\end{array}$ & \\
\hline $\begin{array}{l}\text { Ramantani et al. } \\
\text { (2014) }\end{array}$ & 29 & GG (55.2\%), DNT (44.8\%) \\
\hline $\begin{array}{l}\text { Uliel-Sibony et } \\
\text { al. (2011) }\end{array}$ & 41 & $\begin{array}{l}\text { Pilocytic astrocytoma ( } 48.8 \%), G G \\
(29.3 \%), \text { Low-grade oligodendro } \\
\text { glioma ( } 14.6 \%) \text {, DNT (7.3\%) (tumors } \\
\text { located in temporal lobe were in } \\
\text { cluded) }\end{array}$ \\
\hline
\end{tabular}

Yang et al.
(2019)
Good: Engel class 1 ( $n=27,90.0 \%)$

Poor: Engel class II ( $n=3,10.0 \%)$,

at last $\mathrm{f} / \mathrm{u}, \mathrm{f} / \mathrm{u}$ duration of mean 3.4 years (range 1

month -8.2 years)

Good: sz free or $\geq 75 \%$ sz reduction ( $n=47,78.3 \%$ )

Poor: $<75 \%$ sz reduction $(n=13,21.7 \%)$,

at 2 years after surgery

Good: $s z$ free or $\geq 75 \%$ sz reduction $(n=38,76.0 \%$ )

Poor: $<75 \%$ sz reduction $(n=12,24.0 \%)$,

at 2 years after surgery

Good: Engel class I $(n=22,75.9 \%)$

Poor: Engel class II-IV ( $n=7,24.1 \%)$,

at last $f / u$, f/u duration of mean 7.3 years (SD, 3.0;

range, $1.3-12.3$ years)

Good: Engel class I ( $n=34,82.9 \%)$

duration of mean 5.3 years (range, $1-13$ years)

Good: sz free $(n=26,66.7 \%)$

Poor: persistent sz ( $n=13,33.3 \%$ )

at last $\mathrm{f} / \mathrm{u}$, f/u duration of median 92 months (range,
Poor: Engel class III-IV ( $n=7,17.1 \%)$, at last $f / u, f / u$ Pre MRI

Age at seizure onset, gender, f/u duration, sz frequency before surgery, sz semiology, drug-resistant epilepsy, duration of video EEG monitoring, generalized ED on EEG, side of tumor location, iEEG monitoring, tumor type, associated FCD

Age at sz onset, age at surgery, gender, EEG concordancy, pathology (simple/complex/nonspecific), malformation of cortical development, f/u duration

Age at sz onset, gender, presence of developmental delay, presence of focal neurological deficit, sz semiology, MR appearance of tumor (typical/atypical/enhanced), utiliza tion of ECOG, pathologic classification of DNT (simple) complex/unclassified), presence of cortical dysplasia

Age at sz onset, gender, duration of epilepsy, age at surgery, presence of developmental delay, presence of focal neurological deficit, sz semiology, MRI appearance of tumor (typical/atypical/enhanced), utilization of ECoG, pathologic classification of DNT (simple/complex/ unclassified), presence

Age at surgery, gender, tumor location, extent of resection, utilization of intraoperative ECOG

\section{Parietal location of tumor} STR

Parietal location of tumor STR Duration of epilepsy $>1$ year STR EEG

sence of generalized ED on Age at seizure onset, duration of epilepsy, semiology, tumor type, utilization of ECOG, GTR/STR, extent of resection

Age at surgery, duration of epilepsy. sz semiology, sz frequency before surgery, tumor type

Age at surgery, sz semiology, sz frequency before surgery, tumor type

Age at onset, age at surgery, duration of epilepsy, generalized sz

Presence of satellite lesions on Age at seizure onset, gender, duration of epilepsy, location of tumor, GTR/STR

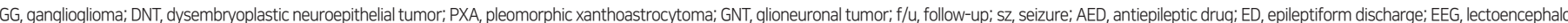

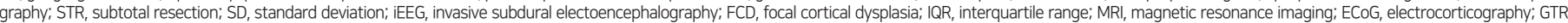
gross total resection.

See the end-reference list in main text for references of the Supplementary Table 1.

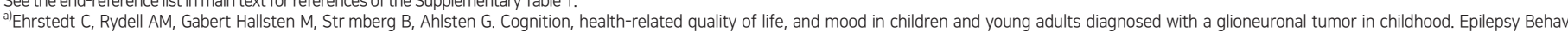
2018:83:59-66. 


\begin{tabular}{|c|c|c|c|c|c|}
\hline Study & $\begin{array}{c}\text { No. of } \\
\text { patients }\end{array}$ & Types of tumor (\%) & Parameters for cognitive functions & $\begin{array}{l}\text { Factors associated with poor } \\
\text { cognitive outcome }\end{array}$ & Factors irrelevant to cognitive outcome \\
\hline \multirow[t]{2}{*}{$\begin{array}{l}\text { Faramand et al. } \\
\text { (2017) }\end{array}$} & 90 & \multirow{2}{*}{$\begin{array}{l}\text { DNT, GG, Demoplastic GG, Angiocentric } \\
\text { glioma, GNT not specified (proportions } \\
\text { unknown) }\end{array}$} & Preoperative full-scale IQ & $\begin{array}{l}\text { Longer duration of epilepsy } \\
\text { Younger age at sz onset }\end{array}$ & Age at surgery, tumor location \\
\hline & 41 & & Postoperative full-scale IQ, at 1 year after surgery & Low preoperative full-scale IQ & $\begin{array}{l}\text { Age at sz onset, duration of epilepsy, degree of } \\
\text { resection }\end{array}$ \\
\hline \multirow[t]{7}{*}{$\begin{array}{l}\text { García- } \\
\text { Fernández et } \\
\text { al. (2011) }\end{array}$} & \multirow[t]{7}{*}{21} & \multirow[t]{7}{*}{$\begin{array}{l}\text { GG (47.6\%), DNT (42.9\%), Gangliocytoma } \\
(9.5 \%)\end{array}$} & $\begin{array}{l}\text { Preoperative full-scale IQ, performance } I Q \text {, motor } \\
\text { function of dominant hand, motor function of } \\
\text { non-dominant hand, verbal reasoning, auditory } \\
\text { processing, vocabulary recognition, visual learning, } \\
\text { arithmetic }\end{array}$ & $\begin{array}{l}\text { Younger age at sz onest } \\
\text { Drug-resistant epilepsy }\end{array}$ & Tumor location, side of tumor location \\
\hline & & & Preoperative verbal IQ, verbal learning & $\begin{array}{l}\text { Younger age at sz onest } \\
\text { Drug-resistant epilepsy } \\
\text { Left hemispheric tumor }\end{array}$ & Side of tumor location \\
\hline & & & $\begin{array}{l}\text { Preoperative vasomotor coordination, visuo- } \\
\text { constructional praxis, spatial memory, concept } \\
\text { formation }\end{array}$ & Younger age at sz onset & $\begin{array}{l}\text { Drug-resistant epilepsy, tumor location, side of } \\
\text { tumor location }\end{array}$ \\
\hline & & & $\begin{array}{l}\text { Preoperative delayed verbal recall, reading/under- } \\
\text { standing }\end{array}$ & $\begin{array}{l}\text { Drug-resistant epilepsy } \\
\text { Left hemispheric tumor }\end{array}$ & Age at sz onset, side of tumor location \\
\hline & & & $\begin{array}{l}\text { Preoperative visual perception, phonemic and } \\
\text { semantic verbal fluency, sustained attention }\end{array}$ & Drug-resistant epilepsy & $\begin{array}{l}\text { Age at sz onset, tumor location, side of tumor } \\
\text { location }\end{array}$ \\
\hline & & & $\begin{array}{l}\text { Preoperative visual perception, phonemic and } \\
\text { semantic verbal fluency, sustained attention }\end{array}$ & Extratemporal location of tumor & $\begin{array}{l}\text { Age at sz onset, drug-resistant epilepsy, side of } \\
\text { tumor location }\end{array}$ \\
\hline & & & $\begin{array}{l}\text { Postoperative improvement in visual attention, } \\
\text { auditory processing, verbal comprehension, verbal } \\
\text { delayed recall, spatial memory, executive function/ } \\
\text { nonverbal fluency, at } 1 \text { year after surgery }\end{array}$ & $\begin{array}{l}\text { Extended lesionectomy (compared } \\
\text { to extended resection) }\end{array}$ & Not mentioned \\
\hline $\begin{array}{l}\text { Giulioni et al. } \\
\text { (2017) }\end{array}$ & $\begin{array}{c}\text { Not } \\
\text { specified }\end{array}$ & $\begin{array}{l}\text { GG, DNT, PXA, Pilocytic astrocytoma, } \\
\text { Angiocentric glioma, GNT not specified, } \\
\text { Low-grade glioma not specified, Mixed } \\
\text { (proportions unknown) }\end{array}$ & $\begin{array}{l}\text { Preoperative neuropsychological test (normal vs } \\
\text { pathologic) }\end{array}$ & Longer duration of epilepsy & Not mentioned \\
\hline \multirow[t]{2}{*}{ Ko et al. (2019) } & 58 & $\begin{array}{l}\text { GG }(46.6 \%), \text { DNT ( } 48.3 \%) \text {, Pilocytic astro- } \\
\text { cytoma (3.4\%), Papillary glioneuronal } \\
\text { tumor (1.7\%) }\end{array}$ & Preoperative full-scale IQ & $\begin{array}{l}\text { Univariate: } \\
\text {-Longer duration of epilepsy } \\
\text {-Greater number of AEDs taken } \\
\text { before surgery } \\
\text {-STR } \\
\text {-Multilobar involvement of tumor } \\
\text { Multivariate: } \\
\text {-Longer duration of epilepsy }\end{array}$ & $\begin{array}{l}\text { Age at seizure onset, gender, age at surgery, f/ } \\
\text { u duration, sz frequency before surgery, sz } \\
\text { semiology, drug-resistant epilepsy, duration of } \\
\text { video EEG monitoring, generalized ED on EEG, } \\
\text { side of tumor location, iEEG monitoring, tumor } \\
\text { type, associated FCD }\end{array}$ \\
\hline & 42 & (proportions unknown) & $\begin{array}{l}\text { Postoperative full-scale IQ, at median } 21.0 \text { months } \\
\text { (IQR, 13.2-31.0 months) after surgery }\end{array}$ & Low preoperative full-scale IQ & Not mentioned \\
\hline \multirow[t]{2}{*}{$\begin{array}{l}\text { Ramantani et } \\
\text { al. (2014) }\end{array}$} & 25 & GG, DNT (proportions unknown) & Preoperative full-scale IQ & Longer duration of epilepsy & $\begin{array}{l}\text { Age at sz onset, age at surgery, sz frequency } \\
\text { before surgery, generalized sz }\end{array}$ \\
\hline & 24 & & Postoperative full-scale IQ & Low preoperative full-scale IQ & Not mentioned \\
\hline
\end{tabular}

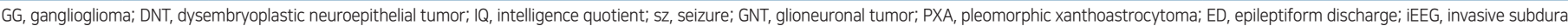
electoencephalography; FCD, focal cortical dysplasia; IQR, interquartile range.

See the end-reference list in main text for references of the Supplementary Table 2. 